\title{
Factors Affecting the Duration of Disease in Chronic Urticarial; Single Center Experience
}

\author{
Kronik U rtikerde Hastalik Su resini Etkileyen Fakto rler: Tek Merkez Deneyimi
}

${ }^{1}$ Department of Internal Medicine, Adana City Training and Research Hospital, Adana, Turkey

${ }^{2}$ Department of Internal Medicine and Allergy, Immunology, Adana City Training and Research Hospital, Adana, Turkey

Correspondence:

Mehmet BANKIR

Department of Internal Medicine, Adana City Training and Research Hospital, Adana, Turkey

e-mail:

mehmet_bankir@hotmail.com

\section{Abstract}

Chronic urticaria (CU) is characterized by recurrent itchy blisters, angioedema, or both for more than six weeks. We evaluated patients' clinical and demographic characteristics, laboratory results, and factors affecting the disease's duration followed up with the diagnosis of chronic urticaria in our clinic. In our study 101 patients who applied to our outpatient clinic between March and December 2020 were included in the study. Demographic features, comorbid illness of patients, skin prick test results, phadiatop, Total IgE, anti-TPO, vitamin B12, vitamin D, ferritin, complete blood count, autologous serum skin test, urticaria activity score over seven days (UAS7) were examined from hospital records retrospectively. Correlations between variables and their effects on the duration of the disease were statistically investigated. It was observed that the duration of the disease was longer in chronic urticaria patients with anti-TPO positivity $(\mathrm{p}=0.019)$. As a result of the multiple regression analysis, it had been determined that the UAS7 value had 2,989 folding effects on the duration of the disease. A positive correlation between the duration of the disease and the UAS7 $(r=0,277 ; \mathrm{p}=0,005)$ was determined. The patients in the study defined as a longer disease duration in the patients with angioedema $(\mathrm{p}=0,005)$, dermatographism $(\mathrm{p}=0,012)$ and gender of female $(\mathrm{p}=0,031)$ Anti-TPO positivity, concomitant angioedema, dermatographism, and higher UAS7 scores predicts that their chronic urticaria will last longer.

Keywords: Chronic urticaria, disease duration, anti-TPO, ASST, Urticaria activity score (UAS7), dermatographism
Kronik ürtiker (KÜ), altı haftadan uzun süredir tekrarlayan kaşıntılı büller, anjiyoödem veya her ikisi ile karakterizedir. Kliniğimizde kronik ürtiker tanısı ile takip edilen hastaların klinik ve demografik özelliklerini, laboratuvar sonuçlarını ve hastalık süresini etkileyen faktörleri değerlendirdik. Çalışmaya Mart-Aralık 2020 tarihleri arasında polikliniğimize başvuran 101 hasta dahil edildi. Hastaların demografik özellikleri, komorbid hastalıkları, deri prik testi sonuçları, phadiatop, Total IgE, anti-TPO, vitamin B12, vitamin D, ferritin, tam kan sayımı, otolog serum deri testi(ASST), haftalık ürtiker aktivite skoru (UAS7) hastane kayıtlarından geriye dönük incelendi. Değişkenler arasındaki ilişkiler ve bunların hastalık süresine etkileri istatistiksel olarak araștırıldı. Anti-TPO pozitifliği olan kronik ürtikerli hastalarda hastalık süresinin daha uzun olduğu görüldü ( $\mathrm{p}=0.019$ ). Yapılan multıple regresyon analizinde UAS7 değerinin hastalık süresi üzerinde 2,989 kat etkisi olduğu tespit edilmiștir. Hastalık süresi ile UAS7 $(\mathrm{r}=0,277 ; \mathrm{p}=0,005)$ arasında pozitif korelasyon saptandı. Anjiyoödem $(\mathrm{p}=0,005)$, dermatografizm $(\mathrm{p}=0,012)$ ve kadın cinsiyeti $(p=0,031)$ olan hastalarda daha uzun hastalık süresi olduğu saptandı. Anti-TPO pozitifliği, eşlik eden anjiyoödem, dermatografizm ve daha yüksek UAS7 skorları, kronik ürtikerlerinin daha uzun süreceğini öngörmektedir.

Anahtar Kelimeler: Kronik ürtiker, hastalık süresi, anti-TPO, Otolog serum deri tetsti (ASST), Ürtiker aktivite skoru (UAS7), dermatografizm 


\section{Introduction}

Chronic urticaria (CU) lasts more than six weeks, characterized by recurrent itchy blisters, angioedema, or both, divided into two main groups as chronic spontaneous urticaria and chronic inducible urticaria. Chronic spontaneous urticaria (CSU) accounts for about $80 \%$ of chronic urticaria and occurs without a specific cause. Prevalence of CSU is $0.5 \%$ to $1 \%$ (1). Chronic inducible urticaria subgroups are; cholinergic urticaria, symptomatic dermatographism, aquagenic urticaria, cold urticaria, hot urticaria, late pressure urticaria, and vibration urticaria. Although the etiology of the disease is not known clearly, two main mechanisms related to the pathogenesis of the disease are considered. The first is the irregularity or defect of the intracellular signaling pathways of basophil and mast cells. In contrast, the second is the development of autoantibodies against the Fc part of Ig E or Fc Epsilon RI alpha (FcRI $\alpha)$ in both basophil and mast cells (2). It has been reported that the rate of physical urticaria association (most common symptomatic dermatographism and late pressure urticaria) is between $10-50 \%(3)$.

Second-generation $\mathrm{H} 1$ anti-histamine drugs are the first line of treatment. The regular dosage of second-generation H1antihistamines could be increased up to 4 times if symptoms are not resolved or improved within the first 2-4 weeks of treatment. If there is still insufficient improvement after 2-4 weeks, omalizumab can be added to the treatment (1). Omalizumab is a recombinant DNA-derived humanized monoclonal antibody that binds to the $\operatorname{IgE}$ molecule and blocks the interaction between free $\operatorname{IgE}$ with $\operatorname{IgE}$ receptors $(4,5)$. This leads to a down regulation of highaffinity $\mathrm{IgE}$ receptor expression on inflammatory cells (6). Remission occurs in $30 \%$ to $50 \%$ of adult patients within $1-3$ years after the onset of symptoms (7). $11 \%$ of patients with $\mathrm{CU}$ symptoms continue longer than five years. In severe cases, the disease may take a longer time (8). Several studies have shown a positive association between autoimmune thyroid disease and CSU in adult patients, and a higher prevalence of serum IgG autoantibodies have been noted for thyroid peroxidase (TPO) and thyroglobulin (TG) (9-13).

We planned to investigate the clinical and demographic characteristics of patients, lab results, and factors affecting the duration of the disease followed up with the diagnosis of chronic urticaria in our clinic.

\section{Methods}

In our study one hundred one patients who applied to our outpatient clinic between March and December 2020 were included in the study. Informed consent was taken from all of the patients. Demographic features, comorbid illness of patients and results of skin prick test, phadiatop (Phadia, Uppsala, Sweden) Total IgE, anti-TPO (Immunoassay), vitamin $\mathrm{B} 12$, vitamin $\mathrm{D}$, ferritin, complete blood count, autologous serum skin test, urticaria activity score were taken from hospital records retrospectively. After obtaining informed consent, skin prick tests and autologous serum test was done patients who do not use anti-histamine medication. Patients under 18 and over 65 years of age, history of malignancy, pregnant and breastfeeding women, and patients who received immunosuppressive therapy were excluded from the study. All of them were followed up; their remission period of $\mathrm{CU}$ was determined and reported as disease duration.

Ethics Ethical approval was obtained in the local ethics committee (2.Oct.2020 104/27), and the study followed Good Clinical Practice guidelines and the Declaration of Helsinki.

Skin Prick test: In the last 10 days, a skin prick test was performed for those who did not take anti-histamine or steroid drugs and those who did not have an acute infection. Pregnant women with chronic spontaneous urticaria were excluded. Mixtures of mites and molds, cat, dog, cockroaches, grass, cereals, tree pollen, weed mixture antigens were used in skin prick tests (ALK, Allergo). It was evaluated 15 minutes after the skin prick test was performed. The two longest diameters that cut each other perpendicularly were measured. If the result is more than 3 
mm compared to the negative control, the test was accepted as positive (14).

Autologous serum skin test (ASST): $5 \mathrm{cc}$ Venous blood $(5 \mathrm{cc})$ taken from patients was allowed to coagulate at the temperature room for 30 minutes. Serum was separated by centrifugation at $500 \mathrm{~g}$ in 15 minutes by creating a 45 degree angle with insulin or tuberculin injector; $0.05 \mathrm{ml}$ serum was administered intradermally. As a negative control (same dose), sterile saline was applied in the same way. Thirty minutes after the injection, the diameter of the erythematous papule was measured. $1.5 \mathrm{~mm}$ larger than negative control was accepted as positive. An autologous serum test is often used to show circulating antibodies that cause urticaria (15).

Dermatographism: Linear urticarial plaque developed five minutes after stroking the skin on the patient's forearm or the upper back with a wooden stick is called dermatographism.

Urticaria activity score (UAS7): It is used to evaluate the severity of urticaria. It includes the number of swelling and itching severity daily for seven days. UAS7 means $\leq 6$ well controlled, 7-15 mild, 16-27 medium, 28-42 severe diseases (16).

Phadiatop: It's a screening test for atopy, including multi-allergen $\operatorname{IgE} \mathrm{E}$, and correlates with skin test results (17).

Statistics: SPSS (Statistical Package for the Social Sciences) 23.0-package program was used for the statistical analysis of the data. Categorical measurements were summarized as numbers and percentages, continuous measurements as mean and standard deviation (median and minimum-maximum where

Table 1. Demographic features of patients necessary). The suitability of the variables to normal distribution was examined using the Shapiro-Wilk Tests. Independent student's test was performed in paired groups for parameters showing normal distribution, and Mann Whitney $u$ test was analyzed for parameters not showing normal distribution. A multiple regression model was used to determine the relationship between disease duration and other parameters. A value of $p$ $<0.05$ was considered to be significant in statistical analysis.

\section{Results}

In our study, $70.3 \%$ of patients were female, $\% 56.4$ of patients didn't have any allergic disease in their family, $59.4 \% \quad(n=60)$ of patients had dermatographism (a subgroup of physical urticaria). The mean age was 39 ; mean disease duration was 39.5 months. 20.79 $\% \quad(n=21)$ of patients had skin prick test positivity, almost mite sensitivity, 24.8 \%patients had positive phadiatop value, and $43.6 \%$ patients had comorbid as an allergic disease. Acute exacerbation with nonsteroidal anti-inflammatory drugs was seen in $37.6 \%$ of patients. $50.5 \%$ of patients with chronic urticarial had angioedema. No smoking history was had in $68.3 \%$ of patients. Any patient was not well controlled (UAS7 means $\leq 6$ ). 9 patients had mild (UAS7means 7-15), seven patients had medium (UAS7 means 16-27) disease, and 85 patients had severe (UAS7 means 28-42) disease. $43,6 \%$ of patients received omalizumab treatment because of inadequate treatment with anti-histamine drugs despite the four-fold increase. Demographic characteristics, skin test results, laboratory values, disease-related findings of the patients were shown in tables 1 and 2 .

\begin{tabular}{lll}
\hline Gender & $\begin{array}{l}\text { Frequency } \\
\text { (n) }\end{array}$ & Percent (\%) \\
\hline Female & 71 & 70.3 \\
Male & 30 & 29.7 \\
\hline Smoking & & \\
\hline No & 69 & 68,3 \\
\hline Yes & 32 & 31,7 \\
\hline Angioedema & & \\
\hline No & 50 & 49,5 \\
\hline Yes & 51 & 50,5 \\
\hline
\end{tabular}




\begin{tabular}{lll}
\hline "NSAID usage & & \\
\hline Exacerbation (-) & 63 & 62,4 \\
\hline Exacerbation (+) & 38 & 37,6 \\
\hline Allergic disease & & \\
\hline No & 57 & 56,4 \\
Yes & 44 & 43,6 \\
\hline Dermatographism & & \\
\hline No & 41 & 40,6 \\
\hline Yes & 60 & 59,4 \\
\hline Family History for allergic disease & & \\
\hline No & 57 & 56,4 \\
\hline Yes & 44 & 43,6 \\
\hline Autologous serum skin test (ASST) & & 60,4 \\
\hline Negative & 61 & 39,6 \\
\hline Positive & 40 & \\
\hline Skin Prick Test & & 27,63 \\
\hline Negative & 38 & 20,79 \\
\hline Positive & 21 & 22,77 \\
\hline Dermographism & 23 & 18,81 \\
\hline None & 19 & 72,3 \\
\hline Phadiatop & & 24,8 \\
\hline Negative & 73 & 3 \\
\hline Positive & 25 & 56,4 \\
\hline Unknown & 3 & 43,6 \\
\hline Treatment & & \\
\hline Anti-histamine drugs & 57 & \\
\hline Anti-histamine drugs + omalizumab & 44 & \\
\hline NSAID: non-steroidal anti-inflammatory drug & & \\
\hline
\end{tabular}

Table 2. Mean and median values of variables

\begin{tabular}{lll}
\hline & Mean $\pm \mathbf{s s}$ & Median (min-max) \\
Age & $39,0 \pm 12,8$ & $39(20-65)$ \\
Disease duration (month) & $39,5 \pm 37,4$ & $25(2-132)$ \\
Urticaria activity score (UAS7) & $33,2 \pm 8,86$ & $35(7-42)$ \\
Eosinophil count $(\mu / \mathrm{l})$ & $207 \pm 156,5$ & $150(100-800)$ \\
IgE E level $(\mathrm{IU} / \mathrm{ml})$ & $252,6 \pm 294,5$ & $122(6-1418)$ \\
Anti-Tpo kU/L & $52,4 \pm 216,5$ & $0,9(0,25-1637)$ \\
Lymphocyte $(\mu / \mathrm{l})$ & $2199 \pm 632,3$ & $2200(900-3700)$ \\
Neutrophil/lymphocyte (NLO) & $2,77 \pm 3,96$ & $2,24(0,95-40,5)$ \\
D vitamin & $17,8 \pm 7,2$ & $16,7(6-34)$ \\
Ferritin $\mu \mathrm{g} / \mathrm{L}$ & $38,6 \pm 50,4$ & $24,5(2,2-374)$ \\
Vitamin B12 & $194,3 \pm 100,5$ & $165,5(68-585)$ \\
\hline
\end{tabular}

Ant1-TPO level compared with variables below and above nine because our reference value for anti-TPO is $0-9 \mathrm{kU} / \mathrm{L}$. It was observed that the duration of the disease was longer in chronic urticaria patients with antiTPO values above $9 \mathrm{kU} / \mathrm{L}(\mathrm{n}=20$ 19.8\%) compared to those below $9 \mathrm{kU} / \mathrm{L} \quad(\mathrm{n}=81)$ $(p=0,019)$. It was observed that the frequency of hypothyroidism increased in values above normal $(p=0.024)$. As a comorbid disease, eleven patients had hypothyroidism, and one patient had hyperthyroidism. According to anti-TPO values, there was no statistical differences in gender, age, smoking history, concomitant angioedema, dermatographism, family history of allergic disease, treatment groups (anti-histamine, anti-histamine + omalizumab), phadiatop, $\mathrm{T}$ IgE, allergenspecific IgE E, UAS7 variables

As a result of the multiple regression analysis, it has been determined that the UAS7 value has 2,989 folding effects on the duration of the disease (Table 3). In addition to this, a positive correlation between the duration of the disease and the UAS7 $(r=0,277 ; p=0,005)$ was determined. There was a weak inverse 
correlation between UAS7 values and vitamin $\quad B 12$ values $(r=0,203)$ of the patients $(p<0,05)$.

Table 3. Effect of variables on disease duration

\begin{tabular}{|c|c|c|c|c|c|c|c|}
\hline \multirow[t]{2}{*}{ Model } & \multicolumn{2}{|c|}{$\begin{array}{l}\text { Unstandardized } \\
\text { Coefficients }\end{array}$} & $\begin{array}{l}\text { Standardized } \\
\text { Coefficients }\end{array}$ & \multirow[t]{2}{*}{ t } & \multirow[t]{2}{*}{ Sig. } & \multirow{2}{*}{$\begin{array}{l}95,0 \% \\
\text { Interval } \\
\text { Lower } \\
\text { Bound }\end{array}$} & \multirow{2}{*}{$\begin{array}{c}\text { Confidence } \\
\text { Upper } \\
\text { Bound }\end{array}$} \\
\hline & B & $\begin{array}{l}\text { Std. } \\
\text { Error }\end{array}$ & Beta & & & & \\
\hline (Constant) & $-115,838$ & 125,156 & &,- 926 & ,367 & $-378,780$ & 147,104 \\
\hline UAS & 2,989 & 1,401 & ,665 & 2,133 & ,047 &, 046 & 5,932 \\
\hline IGE &, 004 &, 032 &, 036 &, 137 &, 892 &,- 062 &, 071 \\
\hline D vitamin &,- 184 & 1,168 &,- 036 &,- 158 & ,876 & $-2,638$ & 2,270 \\
\hline ASST & $-1,897$ & 18,596 &,- 027 &,- 102 &, 920 & $-40,965$ & 37,172 \\
\hline Eosinophil & ,006 & ,048 &, 027 &, 124 & ,902 &,- 094 & , 106 \\
\hline Neutrophil & ,039 &, 025 & 1,382 & 1,565 &, 135 &,- 013 &, 090 \\
\hline Lymphocyte &, 036 &, 038 &, 652 & ,936 &, 362 &,- 045 & ,116 \\
\hline $\mathrm{NLO}^{*}$ & $-17,707$ & 23,055 &,- 517 &,- 768 & 452 & $-66,143$ & 30,729 \\
\hline Leukocyte &,- 026 &, 016 & $-1,378$ & $-1,604$ & ,126 &,- 060 & ,008 \\
\hline Ferritin &, 195 & ,275 &, 169 &, 710 &, 487 &,- 383 &, 773 \\
\hline B12 & ,115 &, 070 & ,371 & 1,639 & ,119 &,- 032 & ,263 \\
\hline Anti-TPO &,- 051 &, 062 &,- 184 &,- 821 & ,422 &,- 182 &, 080 \\
\hline Gender & $-25,132$ & 20,931 &,- 337 & $-1,201$ & ,245 & $-69,105$ & 18,841 \\
\hline Age & ,070 &, 700 & ,029 & ,099 & ,922 & $-1,402$ & 1,541 \\
\hline Smoking & 12,789 & 18,814 & , 172 & ,680 &, 505 & $-26,737$ & 52,315 \\
\hline Angioedema & 8,724 & 19,180 &, 126 &, 455 & ,655 & $-31,571$ & 49,018 \\
\hline NSAID usage & $-15,488$ & 20,595 &,- 220 &,- 752 & ,462 & $-58,756$ & 27,781 \\
\hline $\begin{array}{l}\text { Family allergic } \\
\text { hystory }\end{array}$ & 20,122 & 17,251 & ,286 & 1,166 & ,259 & $-16,121$ & 56,365 \\
\hline SPT positivity & $-17,292$ & 15,183 &,- 254 & $-1,139$ &, 270 & $-49,191$ & 14,606 \\
\hline
\end{tabular}

*Neutrophil to lymphocyte ratio

Model 1: $R=0.680 ; R^{2}=0,462 ;$ Adjusted $R=0,195 ; F=1,473 ; p=0,035$ (Multiple regression analysis)

There was no significant difference between the patient's ASST results (negative or positive) and gender, age, smoking history, concomitant angioedema, dermatographism, family history of allergic disease, treatment groups (anti-histamine, anti-histamine + omalizumab), phadiatop, allergen-specific IgE $\mathrm{E}, \mathrm{T}$ IgE, UAS7 and disease duration of chronic urticaria. When all variables were evaluated statistically according to treatment groups, no significant results were obtained.
The patients in the our study determined as a longer disease duration in the patients with angioedema $(p=0,005), \quad$ dermatographism $(p=0,012)$ and gender of female $(p=0,031)$ (Table 4). No significant result was found when other variables of the study were compared with the duration of the illness of CU.

Table 4.Variables affecting the duration of the disease

\begin{tabular}{|c|c|c|c|}
\hline & & \multicolumn{2}{|c|}{ Disease duration } \\
\hline & & $\begin{array}{l}\text { Mean } \pm \text { ss } \\
\text { Median (min-max) }\end{array}$ & $P$ value \\
\hline Gender & Female & $\begin{array}{l}44,7 \pm 40,9 \\
36(3-132)\end{array}$ & $\mathbf{0 , 0 3 1}$ \\
\hline & Male & $\begin{array}{l}27,1 \pm 23,9 \\
24(2-72)\end{array}$ & \\
\hline Angioedema & No & $\begin{array}{l}29,1 \pm 30,5 \\
19(2-120) \\
\end{array}$ & 0,005 \\
\hline
\end{tabular}




\begin{tabular}{|c|c|c|c|}
\hline \multirow{3}{*}{ Dermatographism } & Yes & $\begin{array}{l}49,6 \pm 41,0 \\
36(3-132) \\
28.2 \pm 334\end{array}$ & \multirow{3}{*}{0,012} \\
\hline & No & $\begin{array}{l}28,2 \pm 33,4 \\
12(2-120)\end{array}$ & \\
\hline & Yes & $\begin{array}{l}47,2 \pm 38,3 \\
38(3-132)\end{array}$ & \\
\hline
\end{tabular}

\section{Discussion}

Chronic urticaria has been reported in association with numerous variables, but CSU's underlying pathology, remission time and associated factors is still unclear. CSU is more common in women, but the relationship between the severity of the disease and gender is unknown (18). The literature found a significant positive correlation between the female gender and the time to remission (19). Like other studies, $70.3 \%$ of female patients were included in our research. Unlikely it was found that female patients had a longer disease duration $(p=0,031)$. It may be due to the high UAS7 levels of the patients included in our study. In multiple regression analysis, it has been determined that the UAS7 value has a 2,989 folding effect on the duration of the disease. Prospective studies have shown that disease severity correlates with disease duration; that is, the more severe disease tends to last longer (20).

Previous studies were reported Comorbidity between inducible urticaria and dermatographism might also be associated with long CU duration $(18,20)$. In our study, $59.4 \%$ of our patients had dermatographism. The long duration of illness was found to be statistically significant in patients with dermographism $(\mathrm{p}=0,012)$.

In the literature 15 of $17(88 \%)$ and 11 of 15 $(73 \%)$ studies found higher IgG anti-TPO and IgG anti-TG levels, respectively, in patients with CSU vs. controls. Only six of 29 (21\%) studies did not report significantly higher rates of $\operatorname{IgG}$ anti-thyroid antibodies in patients with CU than controls (6). A recent meta-analysis and a study with data on 12,778 patients and 10,714 controls were determined that patients with CSU compared to control subjects had significantly higher levels of anti-thyroid peroxidase (anti-TPO) antibodies (21). Levels of IgG-anti-TPO are more often elevated in CSU than those of other thyroid antibodies.
The frequency of hypothyroidism and Hashimoto's thyroiditis are higher than hyperthyroidism and Graves' disease. Thyroid dysfunction is more common in females than in male patients with CSU (22). In our study, 11 patients had hypothyroidism (9 Female, 2 Male), and one female patient had hyperthyroidism. In our study, patients' mean anti-TPO level was $52,4 \pm 216,5 \mathrm{kU} / \mathrm{L}$, and it was observed that the duration of the disease was longer in chronic urticaria patients with anti-TPO values above $9 \mathrm{kU} / \mathrm{L}(\mathrm{n}=2019.8 \%)$ compared to those below $9 \mathrm{kU} / \mathrm{L}(\mathrm{p}=0,019)$. Like our study, Nordyke et al. verified that anti-TPO antibodies had more correlation with thyroid dysfunction than other thyroid antibodies (23). Previous studies showed that thyroid disease might worsen urticaria through activation of the complement system (24). C4a levels decrease when thyroid disease is treated, resulting in remission of $\mathrm{CU}$ (25). Thus, while it is assumed that thyroid disease and CU may coexist due to the patient's predisposition to autoimmunity, thyroid disease may additionally exacerbate urticaria, longer $\mathrm{CU}$ duration through direct mechanisms resulting in complement activation.

There was no significant difference between the patient's ASST results (negative or positive) and all other variables, including disease duration of chronic urticaria. Similar results have been obtained in studies from our country. They found no significant difference in age, gender, atopy, allergic disease, and thyroid autoantibody between ASST negative and positive patients $(26,27)$.

Mete et al. reported lower vitamin B12 levels in 33 patients with chronic urticaria than healthy controls (28). In another study, B12 levels were determined lower in patients with CSU than in the general population (29). In our study, patients' vitamin B12 and vitamin 
D mean values were $194,3 \pm 100,5$ and $17,8 \pm 7,2$, respectively. These values were below the normal reference values. Like our study; reduced low vitamin D level was detected in patients with chronic urticaria (30). In addition to reduced low B12, we found that a weak inverse correlation between UAS7 values and B12 values $(r=0,203)$ of the patients $(p<0,05)$. The absence of a control group is limited to our study.

Greaves $\mathrm{M}$ et al. found that Atopy with $\mathrm{CU}$ was more common in children $(58 \%)$ than in adults (23\%) (31). Our atopy test results for adults were; $20.79 \%$ and $\% 24.8$ for positivity of skin prick test and phadiatop, respectively.

In different published studies, it has been reported that urticaria accompanied by angioedema may also be linked to a longer duration of the disease, and the onset of remission is delayed (18). Approximately 40 to $50 \%$ of $\mathrm{CU}$ patients have concomitant angioedema (32). Similarly, 50.5\% of patients had urticaria concomitant angioedema. These patients had longer disease duration than those without angioedema $(p=0,005)$.

While the remission rate at one year in children might be higher (33), it is about 30 to
$50 \%$ for adult CU patients who do not have an identified triggering factor or underlying disorder (21). We found that 26,73\% of patients were in remission in one year and $39,6 \%$ of patients in two years. In our study mean of illness duration was $39.5 \pm 37,4$. The low remission rate may be due to triggering factors such as NSAID, dermatographism and anti-TPO level, concomitant angioedema. Also, our patients have high UAS7 at the time of admission to our clinic. Drugs such as NonSteroidal Anti-Inflammatory Drugs (NSAIDs) and beta-lactams are well-known triggers for CU (34). NSAIDs may exacerbate skin lesions in up to 25 to $50 \%$ of patients with CU (35). Similar to the literature in our study NSAID's exacerbate urticarial lesions in $\% 37.6$ of patients with chronic urticaria.

\section{Conclusion}

It is crucial to determine the variables that will determine the duration of the disease in chronic urticaria. It has been determined that the UAS7 value has 2,989 folding effects on the duration of the disease. Anti-TPO positivity, concomitant angioedema, dermatographism, and higher UAS7 scores predicts that their chronic urticaria will last longer.

\section{REFERENCES}

1. Zuberbier $\mathrm{T}$, Aberer $\mathrm{W}$, Asero $\mathrm{R}$, et al. The EAACI/GA(2)LEN/EDF/WAO guideline for the definition, classification, diagnosis and management of urticaria. Allergy. 2018;73:1393414.

2. Bracken SJ, Abraham S, MacLeod AS. Autoimmune Theories of Chronic Spontaneous Urticaria. Front Immunol. 2019;10:627.

3. Sanchez-Borges M, Asero R, Ansotegui IJ , et al. Diagnosis and treatment of urticaria and angioedema: a worldwide perspective. World Allergy Organ J. 2012;5:125-47.

4. Maurer M, Rosen K, Hsieh HJ, et al. Omalizumab for the treatment of chronic idiopathic or spontaneous urticaria. $N$ Engl $J$ Med. 2013;368:924-35.

5. Cordeiro Moreira AS, Rosmaninho Lopes de Soares ESMI, Pereira Guilherme MA, et al. Use of omalizumab in the treatment of chronic urticaria. Eur Ann Allergy Clin Immunol. 2016;48:242-6.

6. Holgate ST, Djukanovic R, Casale T, et al. Antiimmunoglobulin $\mathrm{E}$ treatment with omalizumab in

allergic diseases: an update on anti-inflammatory activity and clinical efficacy. Clin Exp Allergy. 2005;35408-16.

7. Quaranta JH, Rohr AS, Rachelefsky GS, et al. The natural history and response to therapy of chronic urticaria and angioedema. Ann Allergy. 1989;62:421-4.

8. Hiragun M, Hiragun T, Mihara S, et al. Prognosis of chronic spontaneous urticaria in 117 patients not controlled by a standard dose of antihistamine. Allergy. 2013;68:229-35.

9. Kolkhir P, Church MK, Weller $\mathrm{K}$, et al. Autoimmune chronic spontaneous urticaria: What we know and what we do not know. J Allergy Clin Immunol. 2017;139:1772-81 e1.

10. Altrichter S, Peter HJ, Pisarevskaja D, et al. IgE mediated autoallergy against thyroid peroxidase--a novel pathomechanism of chronic spontaneous urticaria? PLoS One. 2011;6:e14794.

11. Kolkhir P, Metz M, Altrichter $\mathrm{S}$, et al. Comorbidity of chronic spontaneous urticaria and 
autoimmune thyroid diseases: A systematic review. Allergy. 2017;72:1440-60.

12. Sugiyama A, Nishie H, Takeuchi $\mathrm{S}$, et al. Hashimoto's disease is a frequent comorbidity and an exacerbating factor of chronic spontaneous urticaria. Allergol Immunopathol (Madr). 2015;43:249-53.

13. Kim YS, Han K, Lee JH, et al. Increased Risk of Chronic Spontaneous Urticaria in Patients With Autoimmune Thyroid Diseases: A Nationwide, Population-based Study. Allergy Asthma Immunol Res. 2017;9:373-7.

14. Pepys J. Skin tests for immediate, type I, allergic reactions. Proc R Soc Med. 1972;65:271-2.

15. Konstantinou GN, Asero R, Maurer M, et al. EAACI/GA(2)LEN task force consensus report: the autologous serum skin test in urticaria. Allergy. 2009;64:1256-68.

16. Zuberbier $\mathrm{T}$, Aberer $\mathrm{W}$, Asero $\mathrm{R}$, et al. The EAACI/GA(2) LEN/EDF/WAO Guideline for the definition, classification, diagnosis, and management of urticaria: the 2013 revision and update. Allergy. 2014;69:868-87.

17. Merrett J, Merrett TG. Phadiatop--a novel IgE antibody screening test. Clin Allergy. 1987;17:409-16.

18. Sanchez-Borges M, Caballero-Fonseca F, Capriles-Hulett A, et al. Factors linked to disease severity and time to remission in patients with chronic spontaneous urticaria. $J$ Eur Acad Dermatol Venereol. 2017;31:964-71.

19. Marin-Cabanas I, Berbegal-de Gracia L, de LeonMarrero F, et al. Management of Chronic Spontaneous Urticaria in Routine Clinical Practice Following the EAACI/GA(2)LEN/EDF/WAO Guidelines. Actas Dermosifiliogr. 2017;108:34653.

20. Kozel MM, Mekkes JR, Bossuyt PM, et al. Natural course of physical and chronic urticaria and angioedema in 220 patients. J Am Acad Dermatol. 2001;45:387-91.

21. Confino-Cohen R, Chodick G, Shalev V, et al. Chronic urticaria and autoimmunity: associations found in a large population study. J Allergy Clin Immunol. 2012;129:1307-13.

22. Pan XF, Gu JQ, Shan ZY. The prevalence of thyroid autoimmunity in patients with urticaria: a systematic review and meta-analysis. Endocrine. 2015;48:804-10.

23. Nordyke RA, Gilbert FI, Jr., Miyamoto LA, et al. The superiority of antimicrosomal over antithyroglobulin antibodies for detecting Hashimoto's thyroiditis. Arch Intern Med. 1993;153:862-5.

24. Sibbald RG, Cheema AS, Lozinski A, et al Chronic urticaria. Evaluation of the role of physical, immunologic, and other contributory factors. Int J Dermatol. 1991;30:381-6.

25. Kirkpatrick $\mathrm{CH}$. A mechanism for urticaria/angioedema in patients with thyroid disease. J Allergy Clin Immunol. 2012;130:988-90.

26. Azkur D, Civelek E, Toyran M,et al. Clinical and etiologic evaluation of the children with chronic urticaria. Allergy Asthma Proc. 2016;37:450-7.

27. Sahiner UM, Civelek E, Tuncer A,et al. Chronic urticaria: etiology and natural course in children. Int Arch Allergy Immunol. 2011;156:224-30.
28. 28. Mete N, Gulbahar O, Aydin A, et al. Low B12 levels in chronic idiopathic urticaria. J Investig Allergol Clin Immunol. 2004;14(4):292-9.

29. Wu CH, Eren E, Ardern-Jones MR, et al. Association between Micronutrient Levels and Chronic Spontaneous Urticaria. Biomed Res Int. 2015;2015:926167.

30. WA, Goldner W, Meza J, et al. Reduced vitamin D levels in adult subjects with chronic urticaria. $J$ Allergy Clin Immunol. 2010;126:413; author reply -4 .

31. Greaves M. Chronic urticaria. J Allergy Clin Immunol. 2000;105:664-72.

32. Fine LM, Bernstein JA. Urticaria Guidelines: Consensus and Controversies in the European and American Guidelines. Curr Allergy Asthma Rep. 2015;15:30.

33. Siles R, Xu M, Hsieh FH. The utility of serum tryptase as a marker in chronic spontaneous urticaria. Acta Derm Venereol. 2013;93:354-5.

34. Sanchez J, Sanchez A, Cardona R. Prevalence of Drugs as Triggers of Exacerbations in Chronic Urticaria. J Investig Allergol Clin Immunol. 2019;29:112-7.

35. Zinelli C, Caffarelli C, Strid J, et al. Measurement of nitric oxide and 8-isoprostane in exhaled breath of children with atopic eczema. Clin Exp Dermatol. 2009;34:607-12. 